\title{
Application of XPS and PA techniques in the study of lime used in the Talavera House from the historical center of Mexico City
}

\author{
J. Jiménez-Pérez, A. Bracamontes-Cruz \\ Escuela Nacional de Antropología e Historia \\ Tlalpan, Cd. de México, 14030, México \\ J. L. Jiménez-Pérez \\ Unidad Profesional Interdisciplinaria en Ingeniería y Tecnología Avanzada, Instituto Politécnico Nacional \\ Gustavo A. Madero, Cd. de México, 07340, México \\ Z. N. Correa-Pacheco \\ CONACYT. Centro de Desarrollo de Productos Bióticos, Instituto Politécnico Nacional \\ Yautepec, Morelos, 62731, México \\ M. Pérez-González \\ Área Acad. de Matemáticas y Física, Instituto de Ciencias Básicas e Ingeniería, Universidad Aut. del Estado de Hidalgo \\ Mineral de la Reforma, Hidalgo, 42184, México \\ A. Cruz Orea \\ Departamento de Física, Centro de Investigación y de Estudios Avanzados, Instituto Politécnico Nacional \\ Gustavo A. Madero, Cd. de México, 07360, México \\ (Received: September 3rd, 2020; Accepted: July 1st, 2021)
}

\begin{abstract}
X-ray Photoelectron Spectroscopy (XPS) and Photoacoustic (PA) techniques are useful to identify the structure and optical properties of chemical compounds used in archaeology, among others. In the present study XPS and PA techniques were used to analyze seven samples obtained from the Talavera House, during the conservation and restoration works carried out in the 2012-2013 period. Talavera House is located between the República del Salvador, Talavera and Roldán streets, in the historic center of Mexico City. The objective of this study was to identify the chemical compounds added to the lime when burned in the furnace and its use in the tanneries during the 18th century, both elements located in the second yard, as well as in the construction of the corridor in the 20th century located in the first courtyard. The samples were collected at these points and analyzed by XPS and Photoacoustic (PA) techniques, comparing these results with other excavated sites.
\end{abstract}

\section{Introduction}

Talavera House is located between República del Salvador, Talavera and Roldán streets in the historic center of Mexico City (Cuauhtémoc mayoralty). The property has a perimeter of $30.69 \mathrm{~m}$ to the west, $26.21 \mathrm{~m}$ to the east, $67.52 \mathrm{~m}$ to the south, and $64.29 \mathrm{~m}$ to the north, with a total surface area of 2,095,015 $\mathrm{m}^{2}$. This building was located in a pre-Hispanic neighborhood. Later, it belonged to the Puyade family, being a tannery factory in the 18th century [1-3]. Subsequently, between 1801 and 1892, the Munguía family acquired the house, serving as housing with access on the top floor and accessories on the ground floor [4,5]. Later, the elementary school No. 91 was installed, and a corridor was added to the wall of the first yard, as shown the photograph of Figure 1 (taken by Casasola, 1825-1919). This corridor, as can be seen, have ornamental pots and protections on a wrought iron railing. Today the Talavera House is a site museum and House of Culture.

In 1931, during a technical inspection of the place, the architect Alberto Le Duc [7] notified about the changes to modify the building as a school. In the construction of the south wall corridor in the first yard, wooden beams were used as support, which were subsequently modified by steel beams with meshes of the same material $[8,9]$. This raw material that was integrated into the corridor was eliminated during the restoration works in 2012.

In the period from 1912 to 1915 this house worked as a Superior School called "Antonio Martínez de Castro", with accessories for the sale of liquors, sacks and foodstuffs. In 1931 it was declared historical monument [10]. In 1939 the house has a new owner, the María Goribar de Zaldivar family. In 1976, it was registered in the Department of the Federal District, and in 1977, it is used as a warehouse in its two levels.

In 1984, the building was abandoned, and the ruins were used as dump and it was damaged by a fire caused by the homeless people who lived there. Subsequently, this building was expropriated by the Department of the Federal District during 1984-1986. During this time, the first restoration work was carried out. However, prior to the deterioration, archaeological explorations were done in 1986 . Then, a site museum was adapted in its facilities on the street of República de El Salvador and inaugurated by the president 


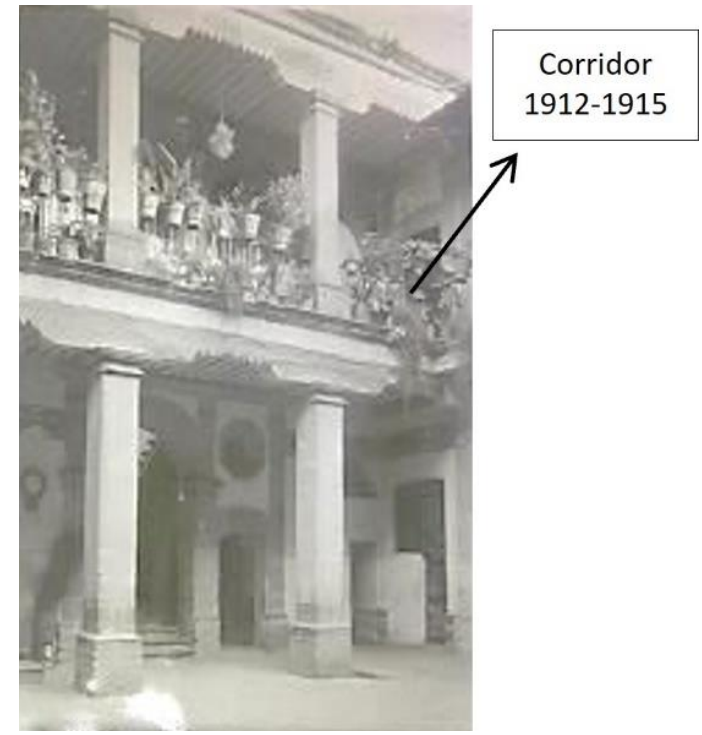

Figure 1. Hall built on the first floor located on the south wall of the first courtyard. Source: photo by Casasola 1825-1919 [6].

Miguel de la Madrid in 1988. This house was registered in the national catalog of historical monuments with the number 090060070537. In 1995, the building was occupied by the Offices of FICAPRO (Trust House Own) and was sheltered by the SEDUVI (Secretariat of Urban Development and Housing). Since 1995, the office of the Coordination of Cultural Diffusion and University Extension are located there. In 1999 minor repairs were made to the building. In the Talavera House, new work was carried out on the conservation and restoration of the first yard and the toilets that are on the first level on the side of the southeast corner of the building in 2012 [11, 12]. By participating in an investigation of the historic archive of this house and reporting new archaeological evidence visible in the restoration work, the importance of lime in the tannery's productive works, as well as the finishes and part of the construction system was applied in this installation, a question arises: Which new materials were added in the lime in the eighteenth century and the difference with the elements used in the twentieth century? The objective of this work was to study the chemical elements that were added to the building during the 18th century. The samples to study were collected at different points of the house and analyzed with the XPS and PA techniques.

\section{Materials and Methods}

Seven powder samples obtained from different parts of the building were analyzed by XPS using a Thermo Scientific K-Alpha spectrometer equipped with a monochromated Al-K $\mathrm{K}_{\alpha}$ source $(h v=1487 \mathrm{eV})$. The spot size was of $400 \mu \mathrm{m}$. Before the analysis, the samples were degassed during $12 \mathrm{~h}$ into the load-lock at a base pressure close to $1 \times 10^{-9}$ Torr. All the signals were calibrated using the $\mathrm{C} 1 \mathrm{~s}$ adventitious hydrocarbon located at $284.6 \mathrm{eV}$. In addition, Shirley backgrounds were used to determine the elemental composition.

On the other hand, the optical absorption spectra of the samples were obtained by using a photoacoustic spectrometer. The samples, in powder form, were placed in a sealed photoacoustic cell, containing air and a photoacoustic sensor. For the analysis, a $1000 \mathrm{~W}$ Xenon lamp (Oriel) was used as a light source. The powders were

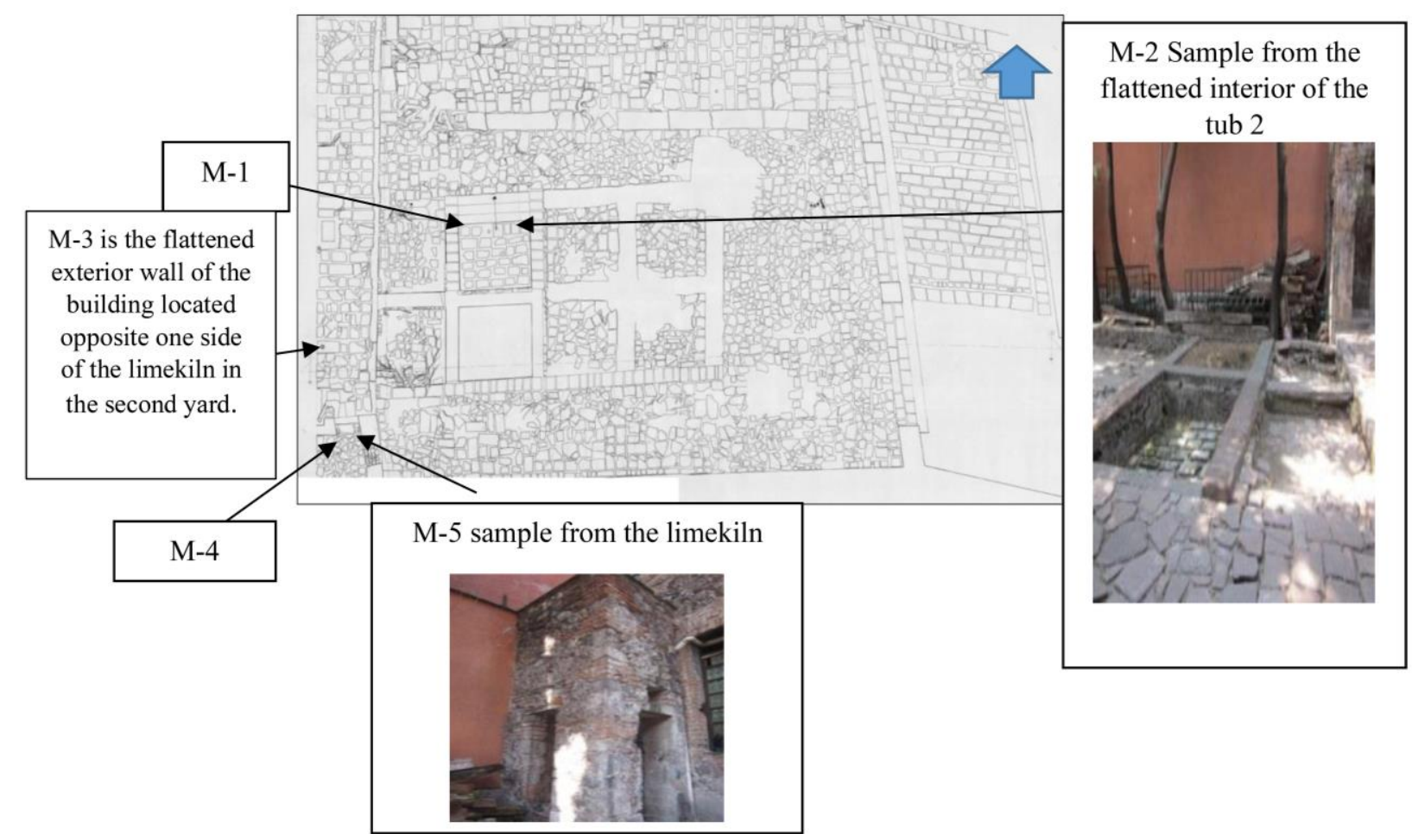

Figure 2. View of the second yard of Talavera House and the location of the samples. 


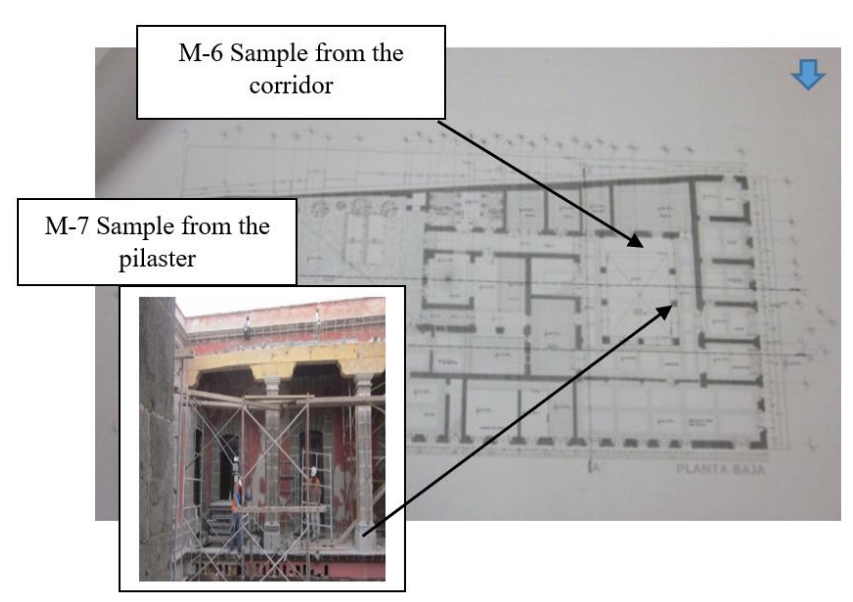

Figure 3. Location of the points in the architectural plant of Talavera House where the samples were obtained.

irradiated through a quartz window, with a monochromatic light. The light intensity was modulated with a chopper at a frequency of $17 \mathrm{~Hz}$. The absorption of light by the powder, and the subsequent thermal de-excitation of the electronic states, generates thermal variation within the material leading to a periodic heat flow from the powder to the surrounding gas. The small modulated thermal changes resulting in the gas pressure variations inside the acoustic cell, these variations were detected by the microphone as sound pressure waves. The wavelength of the incident light was scanned in a range varying from $250 \mathrm{~nm}$ to $800 \mathrm{~nm}$ by means of a monochromator, being the photoacoustic signal recorded on a lock-in amplifier, as a function of wavelength of the incident light, in order to obtain the optical absorption spectra of samples.

Samples M-1 and M-2 were obtained from the flattened interior of the tub 2 in the northwest corner, M-3 from the flattened exterior wall of the building located opposite one side of the limekiln that was in the second yard, the samples M-4 and M-5 correspond to the internal flattened kiln. All these samples were located in the second yard, sample M-6 is part of the building material of the corridor and the last sample M-7, corresponds to the lime that was used as cement between each block of quarry that was part of the pilaster. These last two correspond to spaces of the first yard (Figures 2 and 3 ).

\section{Results and discussion}

From the results of the XPS analysis, the respective atomic percentages for samples M-1 to M-7 were obtained. They are shown in Table 1.

The first samples that were analyzed were taken from the second yard of Talavera House that correspond to tub 2 (samples M-1 and M-2), located in the northwest corner and northeast. In the tannery factory, in these tubs, water and lime were used to wash the leather. Then organic compounds such as tequesquite, sumac, cascalote and huizache were added to tan leather. These materials were used in the year 1797 (18th century) [13].

From the results of the XPS analysis for all samples, nine chemical elements were recognized: oxygen (O 1s), carbon
Table 1. Elemental composition analysis of the Talavera House samples measured by XPS.

\begin{tabular}{cccccccc}
\hline Element & $\begin{array}{c}\text { M-1 } \\
\text { (at\%) }\end{array}$ & $\begin{array}{c}\text { M-2 } \\
\text { (at\%) }\end{array}$ & $\begin{array}{c}\text { M-3 } \\
\text { (at\%) }\end{array}$ & $\begin{array}{c}\text { M-4 } \\
\text { (at\%) }\end{array}$ & $\begin{array}{c}\text { M-5 } \\
\text { (at\%) }\end{array}$ & $\begin{array}{c}\text { M-6 } \\
\text { (at\%) }\end{array}$ & $\begin{array}{c}\text { M-7 } \\
\text { (at\%) }\end{array}$ \\
\hline O 1s & 49.65 & 50.40 & 50.73 & 51.58 & 48.67 & 47.88 & 58.32 \\
C 1s & 34.44 & 34.62 & 32.03 & 31.31 & 34.97 & 35.54 & 16.11 \\
Ca 2p & 9.28 & 11.25 & 6.20 & 10.37 & 8.76 & 9.54 & 3.42 \\
Si 2p & 4.58 & 2.23 & 7.21 & 5.37 & 4.11 & 5.26 & 18.75 \\
Mg 1s & 0.72 & 0.44 & 0.96 & 0.69 & 1.36 & 1.31 & 0.66 \\
P 2p & 0.72 & 0.62 & 0.00 & 0.00 & 1.35 & 0.00 & 0.00 \\
Na 1s & 0.32 & 0.43 & 2.05 & 0.29 & 0.20 & 0.46 & 1.79 \\
Fe 2p & 0.29 & 0.00 & 0.42 & 0.38 & 0.58 & 0.00 & 0.00 \\
K 2p & 0.00 & 0.00 & 0.39 & 0.00 & 0.00 & 0.00 & 0.95 \\
\hline
\end{tabular}

(C 1s), calcium (Ca 2p), silicon (Si 2p), magnesium (Mg 1s), phosphorus (P 2p), sodium ( Na 1s), iron (Fe 2p), and potassium (K 2p). Similar elements have been found for natural limestones and calcareous rocks [14]. Comparing these samples, it is observed that these samples present a high content of oxygen, carbon, calcium and silicon, with each element in several amounts. For instance, the $\mathrm{O} 1 \mathrm{~s}$ was in the range of 47.88 at\% (M-6) up to 58.32 at\% (M-7). Then, the $\mathrm{C} 1 \mathrm{~s}$ was found between 16.11 at $\%$ for $\mathrm{M}-7$ and 35.54 at\% for the M-6 sample, while in the other samples the content of carbon was higher than 30 at\%. Moreover, calcium and silicon were detected in a variable range from 3.42 at\% (M-7) to 11.25 at\% (M-2), and from 2.23 at\% (M-2) to 18.75 at\% (M-7), respectively. The other elements were found in a content lower than 1.79 at $\%$. Comparing M-1 and M-2 samples, that were extracted from the inner part of the walls of the tubs of the tannery, they presented small differences in the $\mathrm{O} 1 \mathrm{~s}$ and $\mathrm{C} 1$ s content, while the first sample displayed more amount of silicon, and the other one presented more calcium.

For sample M-3, from the flattening of the exterior wall of the building located opposite one side of the limekiln in the second yard, it had higher percentages of $\mathrm{Mg}, \mathrm{Fe}, \mathrm{Si}$, and $\mathrm{Na}$ in relation to samples $\mathrm{M}-1$ and $\mathrm{M}-2$. On the other hand, $\mathrm{Ca}$ is in lower percentage, $\mathrm{O}$ and $\mathrm{C}$ have similar percentages and $\mathrm{P}$ is not present in the composition.

For samples M-4 and M-5 inside the limekiln, used to calcine the limestone, alternated with firewood to cover the total inside the furnace, the results of the analysis of the M-4 sample, showed a higher percentage of $\mathrm{O}$ and $\mathrm{Ca}$ compared to M-5. On the other hand, M-5 had a high percentage of $\mathrm{Mg}$ and Fe compared to M-4. M-5 is the sample with the highest content of phosphorous.

In addition, the XPS high-resolution spectra for $\mathrm{O} 1 \mathrm{~s}, \mathrm{C} 1 \mathrm{~s}$, $\mathrm{Ca} 2 \mathrm{p}$, and $\mathrm{Si} 2 \mathrm{p}$ presented below.

In Figure 4, the peaks corresponding to the $\mathrm{O} 1 \mathrm{~s}$ photoelectron lines are shown for the M-1 to M-7 samples. High-resolution peaks were deconvolved, two or three signals were found at different binding energies. All samples displayed a peak at $\sim 530.8 \mathrm{eV}$, attributed to $\mathrm{Ca}-\mathrm{O}$ bonds (indicating the presence of several compounds such as $\mathrm{CaCO}_{3}$ or $\mathrm{Ca}(\mathrm{OH})_{2}$ ), other peaks at $\sim 532.2 \mathrm{eV}$ were assigned to $\mathrm{Si}-\mathrm{O}$ bonds, related to $\mathrm{SiO}_{2}$. The last peak only was observed for the M-3 sample; it was found at $534.6 \mathrm{eV}$, which could be related to adsorbed water on the surface [15]. However, since that signal is placed at a high binding energy, 
it is not completely discarded that it could be attributed to an undetermined compound that overlaps with the $\mathrm{O} 1 \mathrm{~s}$ signal. In Figure 5, the XPS signal for the $\mathrm{C} 1 \mathrm{~s}$ are shown for the complete set of samples. The main peak placed at $284.6 \mathrm{eV}$ due to the adventitious hydrocarbon is attributed to $\mathrm{C}=\mathrm{C}$ or
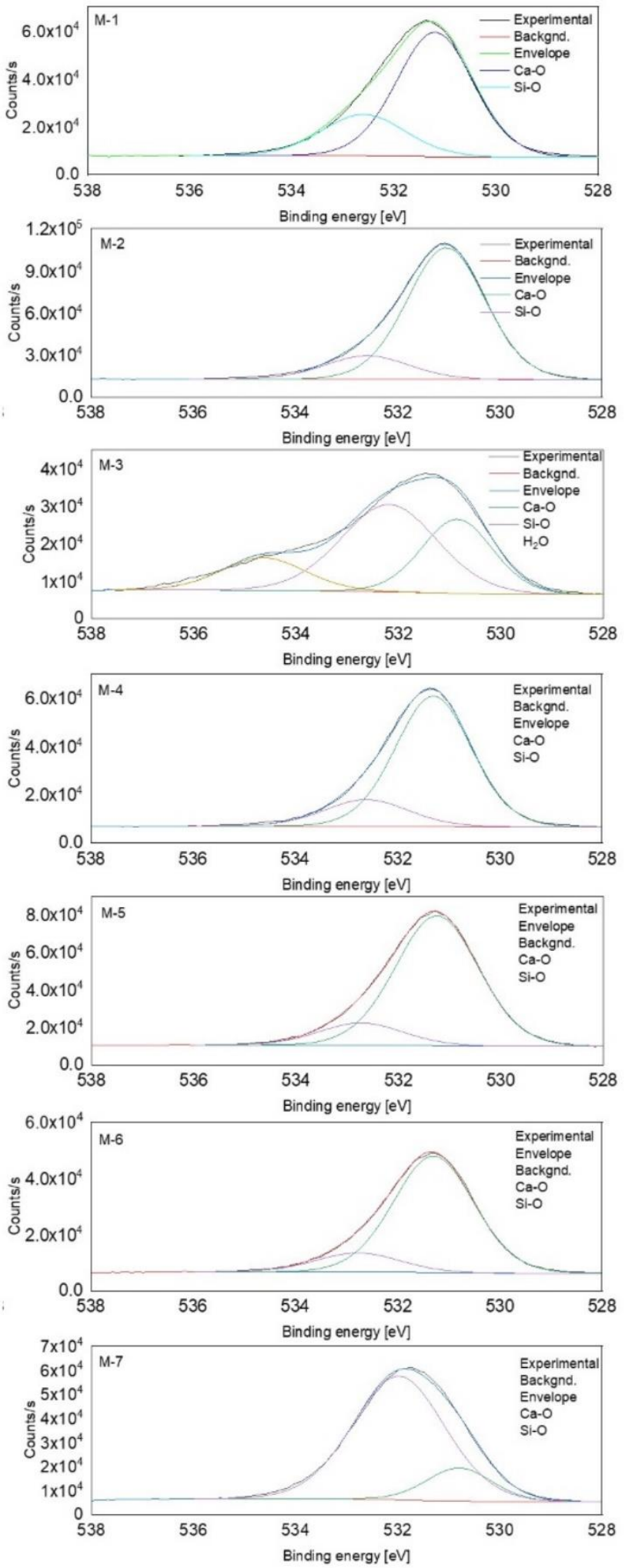

Figure 4. O 1s spectra corresponding to all the samples.
C-H surface bonds, which is due to the sample exposition to the atmosphere [16]. There are more peaks which are observed approximately at $\sim 286.2(\mathrm{C}-\mathrm{O}), 287.8(\mathrm{C}=\mathrm{O})$, and $289.3 \mathrm{eV}$ (assigned to carbonate species), as reported in other
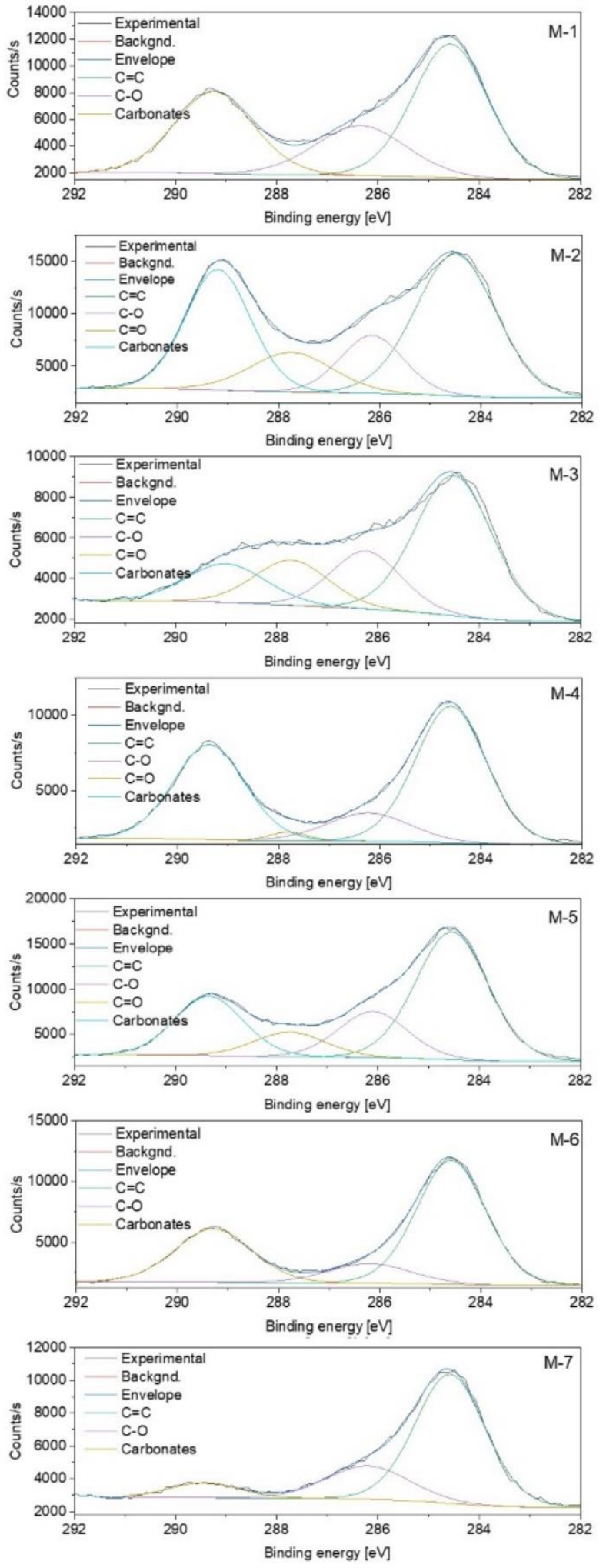

Figure 5. XPS spectra for the $\mathrm{C} 1 \mathrm{~s}$ peaks corresponding to the M-1 - M-7 samples. The doublet place at 291- $298 \mathrm{eV}$ corresponded to the $\mathrm{K} 2 \mathrm{p}$ photoelectron lines. 
works $[17,18]$. In particular, M-1, M-3, and M-7 do not exhibit the $\mathrm{C}=\mathrm{O}$ bond. A possible source of carbonates for samples M-1, M-2, and M-4 could be related with the tub used to tan leather with lime and organic materials.
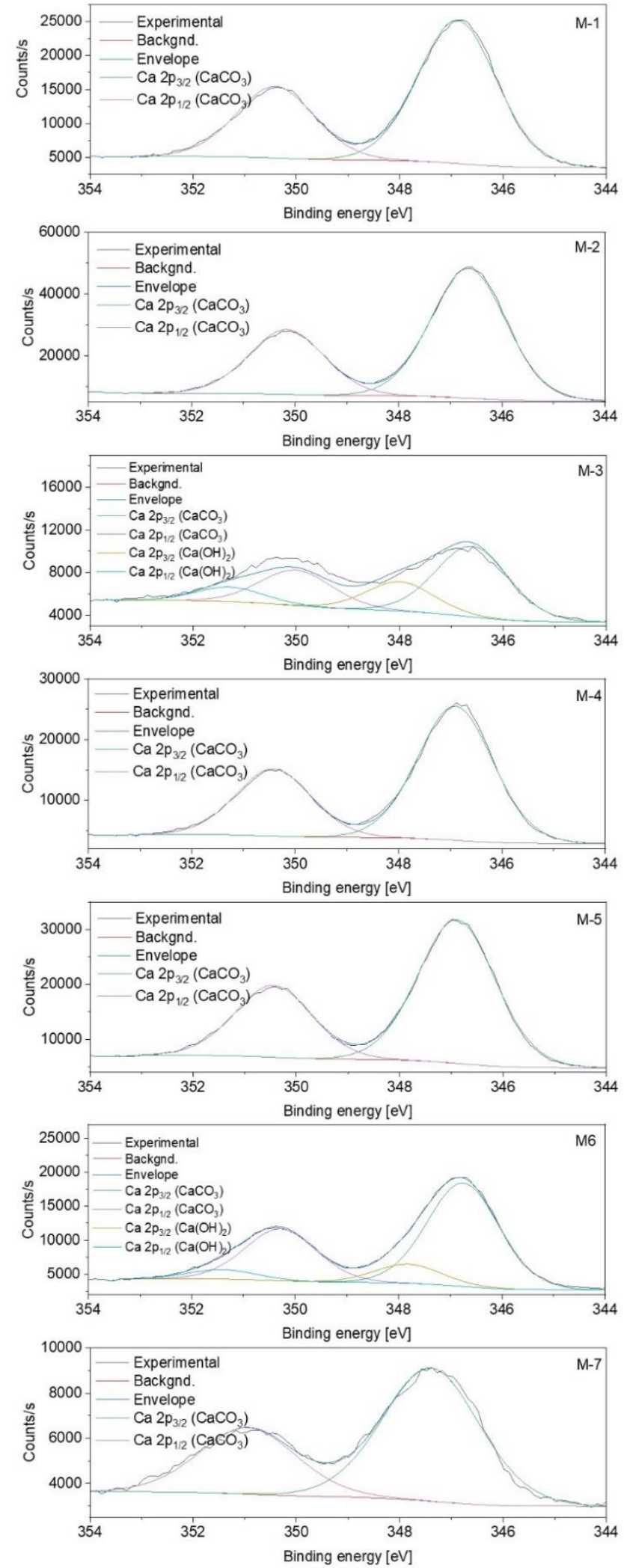

Figure 6. Ca $2 p$ spin-orbit splitting corresponding to the M-1 - M-7 samples.
It should the noted that for the M-3 and M-7 samples, close to the $\mathrm{C} 1 \mathrm{~s}$ peaks, is observed a small doublet assigned to the $\mathrm{K} 2 \mathrm{p}$ peaks in the region from 291 to $298 \mathrm{eV}$ [19].

In Figure 6, the Ca 2p XPS peaks are shown. As seen, all the samples display the characteristic $2 \mathrm{p}_{3 / 2}$ and $2 \mathrm{p}_{1 / 2}$ levels.
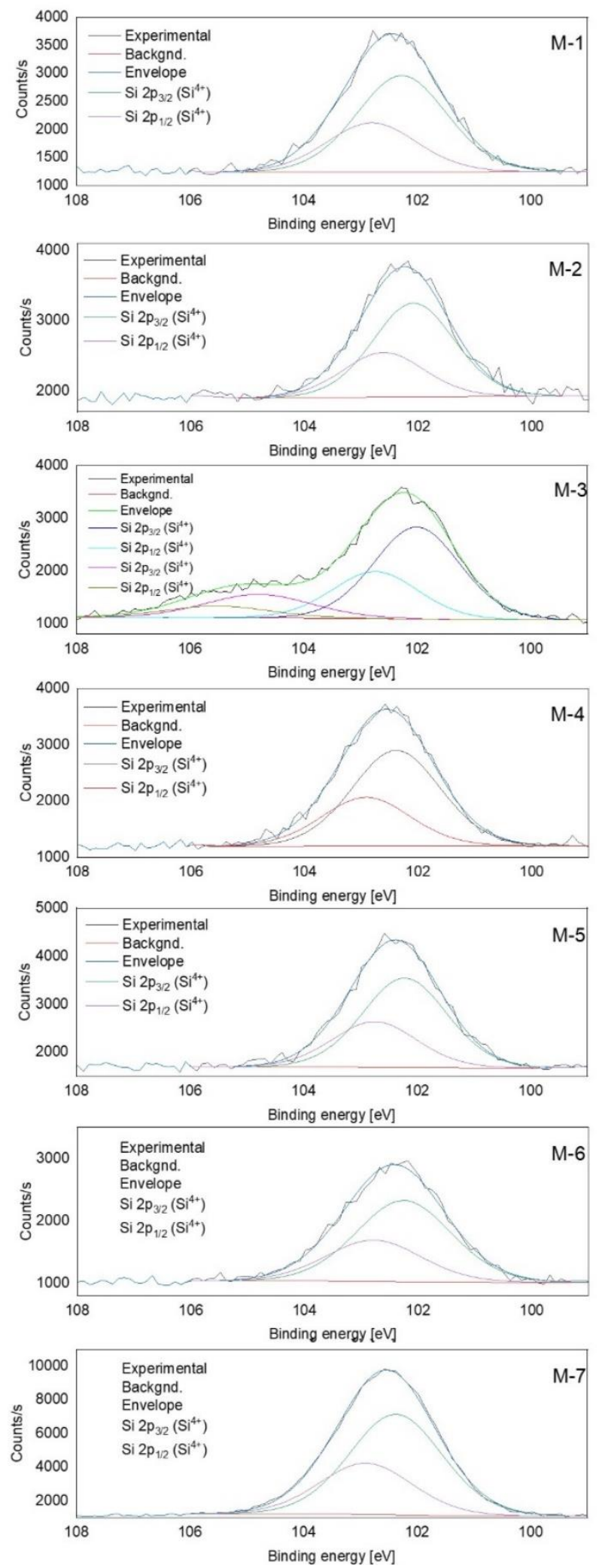

Figure 7. XPS spectra for the Si 2p orbitals corresponding to all the samples. 
When a deconvolution process was performed, it was revealed that M-1, M-2, M-4, M-5, and M-7 samples only displayed a $\mathrm{Ca} 2 \mathrm{p}$ doublet attributed to $\mathrm{CaCO}_{3}$ as reported by Marriot et al. [20]. The same authors have claimed that signals placed at higher binding energies correspond to $\mathrm{Ca}(\mathrm{OH})_{2}$, in our work M-3 and M-6 it is appreciated an extra spin-orbit doublet which can be assigned to $\mathrm{Ca}(\mathrm{OH})_{2}$. The spin-orbit splitting was close to $3.5 \mathrm{eV}$ for all the samples, and the $2 \mathrm{p}_{1 / 2} / 2 \mathrm{p}_{3 / 2}$ ratio was almost 0.5 .

The samples M-6 and M-7 correspond to the first yard. In the sample M- 6 of the corridor all the elements, except P, Fe and K. This corridor was built in the year 1902 when the house was enabled to function as a primary school and was withdrawn in 2012 as we previously mentioned for restoration works of the property.

On the other hand, the sample M-7 obtained from the blocks that join to integrate the pilaster of the year (1797) had the highest percentages of $\mathrm{O}, \mathrm{Si}$ and $\mathrm{K}$. Silicon is the main component of sand, sandstone, quartzite and granite [21]. As seen in Figure 7, the Si 2p XPS peaks are presented between 99 and $108 \mathrm{eV}$ for all the samples. XPS core-level spectra were deconvolved in order to determine the oxidation states of Si 2p. All samples except M-3 displayed the Si $2 \mathrm{p}_{3 / 2}{ }^{4+}$ and $\mathrm{Si} 2 \mathrm{p}_{1 / 2}{ }^{4+}$ oxidation states, indicating that silicates could be formed [22]. In addition, according to Wagner et al. [22], Si 2p peaks at binding energies higher that $103 \mathrm{eV}$ could be associated to oxides and hydroxides. In Figure 8 are displayed the XPS corresponding to $\mathrm{Na} 1 \mathrm{~s}$ and $\mathrm{K} 2 \mathrm{p}$ for the sample M-7, and the $\mathrm{P} 2 \mathrm{p}$ and $\mathrm{Fe} 2 \mathrm{p}$ peaks for $\mathrm{M}-5$. Phosphorus is an essential component of the organisms that are part of the nucleic acids (DNA and RNA), bones and teeth of animals. In plants in a portion of $0.2 \%$ and in animals up to $1 \%$ of its mass is phosphorus. Since the $\mathrm{P} 2 \mathrm{p}$ doublet is placed between 131 and $136 \mathrm{eV}$, with the $\mathrm{P} 2 \mathrm{p}_{3 / 2}$ and $\mathrm{P} 2 \mathrm{p}_{1 / 2}$ signals places at 132.8 and $133.7 \mathrm{eV}$, respectively, indicating that phosphorus oxides have been formed [23]. Potassium is a white-silvery alkali metal, which is abundant in nature in the elements related to saltwater and other minerals [14]. In the case of Fe $2 p$ doublet, as observed for M-5, the Fe content is too low, generating a signal hard to be analyzed using a deconvolution method. However, the $2 \mathrm{p}_{3 / 2}$ and $2 \mathrm{p}_{1 / 2}$ components can be appreciated.

When recognizing the chemical composition as a result of the sampling and analysis of the construction materials, it is important to take into account the knowledge of the characteristics of the materials used that will allow a better understanding of the construction systems. Then, it will be more accessible the information of the materials used in the Talavera House building in the two periods of its construction.

As for the generalities of lime, this is an inorganic material, of stone origin and are artificial materials (manufactured). According to González et al.1988 [24] it is described: The quicklime is obtained by calcination of the limestone, with a high content of calcium carbonate $\left(\mathrm{CaCO}_{3}\right)$, at a temperature of about $900{ }^{\circ} \mathrm{C}$ according to the following reaction: $\mathrm{CaCO}_{3}$ + heat $\rightarrow \mathrm{CaO}+\mathrm{CO}_{2}$, the density of calcium oxide is $1000 \mathrm{~kg} / \mathrm{m}^{3}$. The slaked lime is the one that is wet with the water reacts reaching a temperature of $90^{\circ} \mathrm{C}$. The hydraulic lime is the one that hardens quickly under water and the whitewash, is lime mixed with water used to revoke. One of the processes used to prepare lime in the colony was that of air lime, which hardens in the air, by the absorption of carbonic acid from the atmosphere that forms a combination of hydrate and calcium carbonate. The chemical elements that make up this compound were visible in the XPS analysis of the samples, as indicated above.

When a quantity of lime is quenched, it can be stored in a "raft" or "rotten" for years, allowing it to continue to go out and mature. The minimum period to be used is six months. As more years passed, better will be the behavior, carbonating optimally when used in plaster, stucco or mortar. Of course, not all lime quarries offer the same quality of product and the higher percentage of carbonate has a lime, the better quality will be the slaked lime that is $\mathrm{Ca}(\mathrm{OH})_{2}$ (calcium hydroxide), ideal being those approach to the composition of marble.

In ancient times, when the construction of some cathedrals and palaces was begun, the lime pools were prepared, since it was the last element that was used in large quantities and since the construction was very slow, in some cases it lasted more than one century, the lime was maturing for when it was necessary [25].

Kubler makes mention in Mexican architecture of the sixteenth century, that in the constructions of Mexico City used the lime extracted from Zumpango, although most of the lime used in the capital came from Calpulalpan, the fine lime for stucco came from Cozcatlán, south of Puebla [26].

In the sixteenth, seventeenth and eighteenth centuries, lime was used as a binder in mortars, to join stony materials, as a coating in the form of flattening, as a painting for the protection and ornamentation of the building, which in its elaboration commonly adds sand, slime of cactus and vegetal earth as coloring.

Bromatological analyzes of different cactus species have been carried out at the University of Guanajuato, and there was interest in emphasizing that the use of cactus slime has been recognized as a binder to achieve the permeability and resistance of the materials applied in the construction. It was
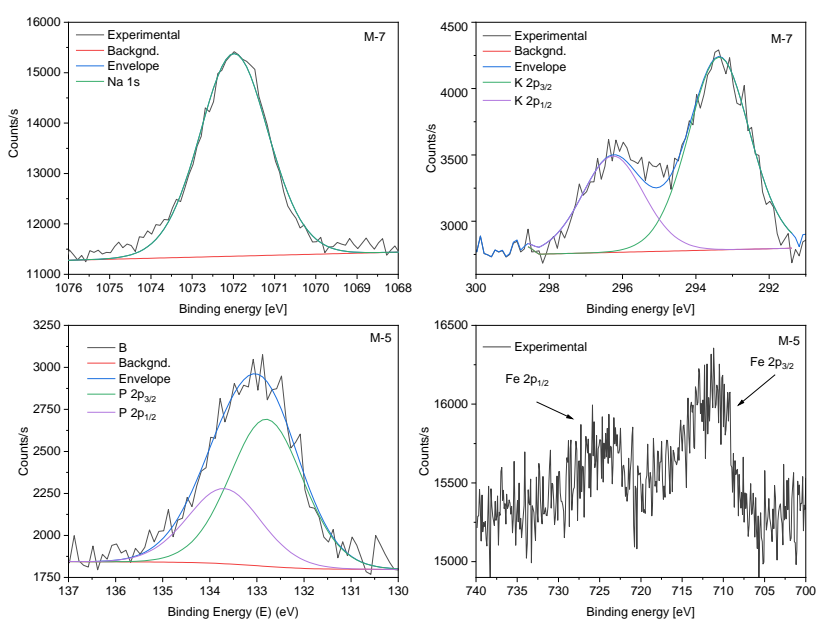

Figure 8. $\mathrm{Na} 1 \mathrm{~s}$ and $\mathrm{K} 2 \mathrm{p}$ signals for M-7. P $2 \mathrm{p}$ and Fe $2 \mathrm{p}$ peaks for the sample M-5. 

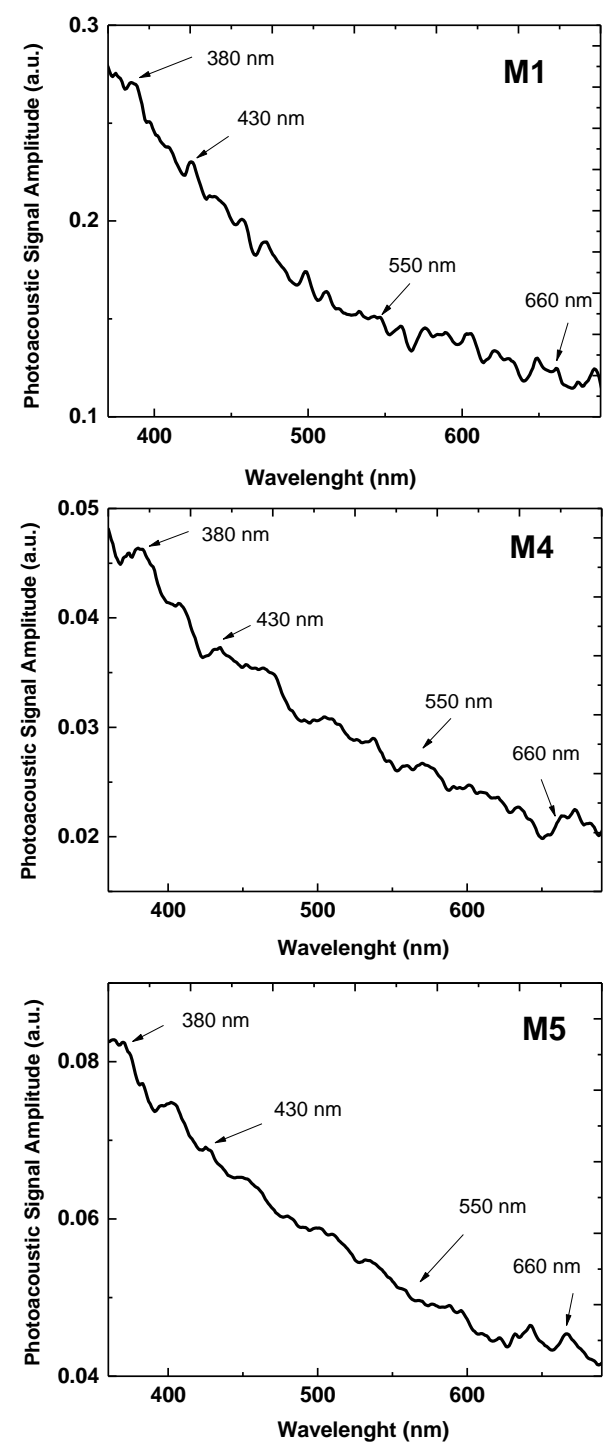

Figure 9. Typical photoacoustic spectra of M1, M4 and M5.

use from pre-Hispanic times to the colony. Nowadays, it is used to restore buildings belonging to these historical periods. And in the case of the painting, the following is stated: the use of the Temple to the slime is difficult to prove, but it was unquestionably used at least in modest works , as suggested by the state of conservation of some pictorial remains.

In the nineteenth century a conglomerate of hydraulic mixture and brick chipping in alternating layers was used as a grid or on the stone foundation, as distribution chains, as well as drowned in concrete, and profuse decoration made of plaster and various stuccos in the ornamentation of soffits. In the 20th century it was used as concrete.

To this lime other materials are applied to obtain mortars made of lime, sand and water used in masonry and stucco that is a mass of plaster and glue. Natural lime presents in some deposits of the State of Hidalgo as in El Refugio, the elements: $\mathrm{C}, \mathrm{O}, \mathrm{Na}, \mathrm{Mg}, \mathrm{Al}, \mathrm{Si}, \mathrm{Ca}, \mathrm{Fe}$ and $\mathrm{Cu}$; and in $\mathrm{El}$ Llano $\mathrm{Na}, \mathrm{Mg}, \mathrm{Fe}$ and $\mathrm{Cu}$ are not present. Compared with Talavera House, these percentages are lower and there is no presence of $\mathrm{Al}$ and $\mathrm{Cu}$, which indicates that these elements were not incorporated [27].

On the other hand, photoacoustic spectrum measurement was performed for samples M1-M7. Photoacoustic absorption spectra (PA) for M1, M2, M4 and M5 samples are shown in Figure 9, revealing bands of absorption in the UVvisible, with a wide absorption range from 300 to $900 \mathrm{~nm}$. The samples M1, M3, M4 and M5 had higher percentage of Fe. Sample M1, M3, M4 and M5 had 0.29, 0.42, 0.38 and 0.58 at\% of Fe, respectively, as shown in Table 1 of XPS analyzes. In the PA spectra of these samples, it is observed, that there are absorption bands defined in the literature for samples M1, M4 and M5. These overlapped bands ranging from $380 \mathrm{~nm}$ to $660 \mathrm{~nm}$ with a maxima around $380 \mathrm{~nm}, 430$ $\mathrm{nm}, 550 \mathrm{~nm}$ and $660 \mathrm{~nm}$ corresponding to $\mathrm{Fe}_{3}{ }^{+}$and $\mathrm{Fe}$ oxides [28]. In other words, there is a higher concentration of iron probably due to a minimal reduction of oxygen during its manufacturing, possibly due to a type of cooking in these places, such as in tubs and furnaces where tannery was treated. Similarly, some authors reported the oxides of Fe in this range for the analysis of ancient ceramics, due to the type of cooking that was carried out at different times [29]. Also $\mathrm{Ca}(\mathrm{OH})_{2}$ (calcium hydroxide) absorbs in the UV range of the spectrum.

\section{Conclusions}

In the results of the chemical analysis of Talavera House, from the XPS analysis, nine elements were found: $\mathrm{O}, \mathrm{C}, \mathrm{Ca}$, $\mathrm{Si}, \mathrm{Mg}, \mathrm{P}, \mathrm{Na}, \mathrm{Fe}$ and $\mathrm{K}$, varying their percentages according to the sampled site. For the samples M-1 and M-2 and M-4 and M-5, the elements with higher percentages were $\mathrm{O}, \mathrm{C}$, $\mathrm{Ca}$ and $\mathrm{P}$ being found in the tubs and lime kilns. Therefore, it is concluded that these elements were used as components for the tannery and leather with possible incorporation of organic elements like $\mathrm{P}$ and colorants such as iron oxide.

For samples M-3, M-6 and M-7 that are from the exterior wall and material construction of the corridor and pilaster, it was observed a higher percentage of $\mathrm{Si}$ and $\mathrm{Na}$ which comes from sand, sandstone, quartzite and granite. The presence of $\mathrm{Mg}, \mathrm{O}$ and $\mathrm{Ca}$ were confirmed by XPS. In samples M1, M2, M4 and M5 were found some evidences, also by PA, of Fe and $\mathrm{Fe}$ oxides in the tubs and in the furnaces, possibly for the treatment of leather. Therefore, there was significant differences between samples from the $18^{\text {th }}$ century (M-1, M-4 and M-5) compared to the samples from the $20^{\text {th }}$ century (M-3, M-6 and M-7), due to differences in the proportion of the elements used for construction for these two different periods of the Talavera House.

Similar results obtained by PA, for analysis of ancient ceramics, have reported that the optical absorption spectrum of Fe oxides, in this wavelength range, is due to the type of ceramic firing processes, during its manufacturing, which has varied at different epochs.

\section{Acknowledgements}

Thanks to CONACYT, COFAA, Red-Nanofotónica and CGPI-IPN, México, for their partial financial support. M. Pérez-González acknowledges to PROMEP-SEP (project 
number UAEH-PTC-826), CONACYT (project number 205733), and gratefully acknowledges Prof. Sergio A. Tomás for providing XPS facilities.

\section{References}

[1]. F. De la Maza, L. Ortiz Macedo, Plano de la Ciudad de México de Pedro de Arrieta. (México, UNAM, 2008).

[2]. M. Fernández, Arquitectura y Gobierno Virreinal. Los Maestros Mayores de la ciudad de México, siglo XVIII (México, UNAM, 1985).

[3]. C. Bargellini, G. Curiel, M. Frenández, I. González-Polo, A. Rubial, M. Sánchez, N. Sigaut, La Nobleza Novohispana y sus Palacios. In: Casas Señoriales del Banco Nacional de México (México, Fomento Cultural Banamex, 1999), p. 56.

[4]. J. González Angulo Aguirre, Y. Terán Trillo, Planos de la Ciudad de Mexico, 1785, 1853 y 1896: Con un directorio de calles con nombres antiguos y modernos (México, INAH, 1976), p. 96.

[5]. M. Toussaint, F. Gómez, J. Fernández, Planos de la Ciudad de México, Siglos XVI y VVII, Estudio Histórico, Urbanístico y Bibliográfico. (Mexico, UNAM, 1985).

[6]. G. Casasola, Seis siglos de historia gráfica de México 13251967 (México, Casasola, 1975), p.137.

[7]. A. Le Duc, Casa Talavera, Exp. VIII-2/303(725.1)-106 (Archivo Técnico de la Coordinación Nacional de Monumentos Históricos: Casa Talavera, 1931-1933).

[8]. L. Muro, Historia mexicana 5, 337 (1956).

[9]. J. Urquiaga, La Restauración del antiguo convento hospitalario. In: Antiguo Convento de Betlemitas (México, Banco de México, 2005), p. 243.

[10]. M. Toussaint, Arte Colonial en México. (México, UNAM, 1983), p.17.

[11]. J. Jiménez Pérez, A. Bracamontes Cruz, J.L. Jiménez Pérez, Z.N. Correa Pacheco, A. Cruz Orea, La Casa Talavera (México, Restauro Compás y Canto, 2016).

[12]. R. Vargas Salguero, Historia de la arquitectura y el urbanismo mexicanos. Vol. III (México, FCE, 1998).

[13]. J. Emsley, Nature's Building Blocks: An A-Z Guide to the Elements (UK, Oxford University Press, 2001).

[14]. L. Järvinen, J. Leiro, F. Bjondahl, C. Carletti, O. Eklund, Surf. Interface Anal. 44, 519 (2012).

[15]. S. Yamamoto, T. Kendelewicz, J.T. Newberg, G. Ketteler,

D.E. Starr, E.R. Mysak, K.J. Andersson, H. Ogasawara, H. Bluhm,
M. Salmeron, G.E. Brown, Jr., A. Nilsson, J. Phys. Chem. C 114, $2256(2010)$.

[16]. M. Pérez-González, S.A. Tomás, Catal. Today 360, 129 (2021).

[17]. S. Alijani, S. Capelli, S. Cattaneo, M. Schiavoni, C. Evangelisti, K.M.H. Mohammed, P. P. Wells, F. Tessore, A. Villa, Catalysis 10, $11(2020)$.

[18]. A. Ganguly, S. Sharma, P. Papakonstantinou, J. Hamilton, $J$. Phys. Chem. C 115, 17009 (2011).

[19]. P. Knutsson, V. Kantatore, M. Seemann, P. Lam, I. Panas, Appl. Catal. B: Environ. 229, 88 (2018).

[20]. A.S. Marriott, A.J. Hunt, E. Bergstrom, K. Wilson, V.L. Budarin, J. Thomas-Oates, J.H. Clark, R. Brydson, Carbon 67, 514524 (2014).

[21]. W.L. Pohl, Economic Geology: Principles and Practice (Wiley, USA, 2011), p. 380.

[22]. C.D. Wagner, D.E. Passoja, H.F. Hillery, T.G. Kinisky, H.A. Six, W.T. Jansen, J.A. Taylor, Auger photoelectron line energy relationships in aluminum-oxygen and silicon-oxygen compounds, J. Vac. Sci. Technol. 21, 933 (1982).

[23]. D.A. Granada-Ramirez, J.S. Arias-Cerón, M. Pérez-González, J.P. Luna-Arias, A. Cruz-Orea, P. Rodríguez-Fragoso, J.L. HerreraPérez, M.L. Gómez-Herrera, S.A. Tomás, F. Vázquez-Hernández, A.A. Durán-Ledezma, J.G. Mendoza-Alvarez, Appl. Surf. Sci. 530, 147294 (2020).

[24]. A. González Avellaneda, A. Hueytletl Torres, B. Pérez Méndez, L. Ramos Molina, V. Salazar Muñoz, Manual Técnico de Procedimientos para la Rehabilitación de Monumentos Históricos en el Distrito Federal (México, INAH, 1998).

[25]. R. Mack, J. Speweik, Repointing Mortar Joints in Historic Masonry Buildings. In: The Preservation of Historic Architecture the U.S. governments official guidelines for preserving historic homes (USA, Lyon Press, 2004), p. 20.

[26]. G. Kubler, Arquitectura mexicana del siglo XVI (México

Fondo de Cultura Económica, Mexico, 1984), p.220.

[27]. J. Jiménez-Pérez, A. Bracamontes Cruz, Z. Correa Pacheco, J. L. Jiménez Pérez, A. Cruz Orea, MRS Proceedings 1618, 81 (2014). [28]. A.M. Mansanares, $\mathrm{PhD}$ Thesis, Caracterização fotoacustica de materiais: difusividade térmica e perfil de profundidade (UNICAMP-Brazil, 1991).

[29]. J. L. Jiménez-Pérez, J. Jiménez-Pérez, A. Bracamontes Cruz, A. Cruz-Orea, J. G. Mendoza-Alvarez, A. Gordillo-Sol, H. YeeMadeira, Int. J. Thermophys. 27, 1898 (2006).

(C) 2021 by the authors; licensee SMCTSM, Mexico. This article is an open access article distributed under the terms and conditions of the Creative Commons Attribution license (http://creativecommons.org/licenses/by/4.0/). 